\title{
Nitrogenase of Sesbania Rhizobium Strain ORS571: Purification, Properties and 'Switch-off' by Ammonia
}

\author{
By ANIL KUSH, CLAUDINE ELMERICH AND JEAN-PAUL AUBERT* \\ Unité de Physiologie Cellulaire, Département de Biochimie et Génétique Moléculaire, \\ Institut Pasteur, 75724 Paris Cedex 15, France
}

(Received 26 November 1984; revised 4 February 1985)

\begin{abstract}
Nitrogenase from the Rhizobium strain ORS571, which forms both root and stem nodules on the tropical plant Sesbania rostrata, was purified from free-living diazotrophically grown organisms. The enzyme complex was resolved into two protein components resembling those obtained from other diazotrophs. Both components were purified to homogeneity as judged by SDS-gel electrophoresis. Component 1 , a Mo-Fe protein, had a $M_{\mathrm{r}}$ of 219000 and contained $1.2 \mathrm{~g}-$ atoms $\mathrm{Mo} \mathrm{mol}^{-1}, 22.5 \mathrm{~g}$-atoms $\mathrm{Fe} \mathrm{mol}^{-1}$ and $20.5 \mathrm{~g}$-atoms acid-labile $\mathrm{S} \mathrm{mol}{ }^{-1}$. It consisted of two types of subunit of $M_{\mathrm{r}} 56000$ and 59000 . The specific activity [nmol product formed $\mathrm{min}^{-1}$ (mg protein $)^{-1}$ ] of component 1 , when assayed in the presence of an optimum concentration of component 2 (molar ratio $1: 40$ ), was 1250 for acetylene reduction and 1090 for hydrogen evolution. Component 2, an Fe protein, had a $M_{\mathrm{r}}$ of 74000 and contained $3 \cdot 1 \mathrm{~g}$-atoms $\mathrm{Fe} \mathrm{mol}{ }^{-1}$ and 3.1 g-atoms acid-labile $S \mathrm{~mol}^{-1}$. It consisted of a single type of subunit of $M_{\mathrm{r}} 36000$. The specific activity of component 2 , when assayed in the presence of an optimum concentration of component 1 (molar ratio $1: 1$ ) was 1700 for acetylene reduction and 1305 for hydrogen evolution. Nitrogenase activity of strain ORS571 was subject to 'switch-off' when ammonia was added to a $\mathrm{N}_{2}$-fixing culture. This effect was independent of protein synthesis and was reversible. Nitrogenase components 1 and 2 isolated from 'switched-off' organisms were purified to homogeneity. Both components had the same mobility on SDS-gels as those isolated from active cultures. 'Switch-off' resulted in a decrease in the specific activity of component 2 from 1700 to 280 . Component 1 remained fully active. The addition of $\mathrm{Mn}^{2+}$ to a crude extract containing inactivated nitrogenase did not restore activity.
\end{abstract}

\section{INTRODUCTION}

The fast-growing Rhizobium strain ORS571, isolated from stem nodules of the tropical legume Sesbania rostrata, forms nodules on both stems and roots of the host plant (Dreyfus \& Dommergues, 1981), and can grow in the free-living state at the expense of $\mathrm{N}_{2}$ as sole nitrogen source (Elmerich et al., 1982; Dreyfus et al., 1983). This latter property suggested that the genetics and biochemistry of nitrogen fixation in this strain could be investigated using techniques developed in free-living diazotrophs such as Klebsiella pneumoniae. Isolation of Nifmutants of strain ORS571, cloning of a DNA sequence homologous to $K$. pneumoniae nifHDK and genetic complementation of a mutant with impaired nitrogenase activity have been described by Elmerich et al. (1982), but no data on the enzyme have as yet been published.

Nitrogenase, the enzyme complex that catalyses the reduction of $\mathrm{N}_{2}$ to $\mathrm{NH}_{3}$, has been isolated from a variety of diazotrophs (Eady \& Smith, 1979). In all cases, it has been fractionated into two protein components, a Mo-Fe protein or component 1, a tetramer comprised of two different subunits, and an Fe protein or component 2, a dimer made of a single type of subunit (Eady \& Smith, 1979). The structure of both components appears to have been highly conserved during evolution (Eady \& Smith, 1979). 
We report here a purification procedure and some properties of the nitrogenase of Rhizobium strain ORS571 grown in the free-living state, and also on the regulation of its activity in vivo by added $\mathrm{NH}_{4}^{+}$. A preliminary report of these results has been presented (Norel et al., 1984).

\section{METHODS}

Media and bacterial growth. The minimal nitrogen-free LSO medium and complete YLS medium were described by Elmerich et al. (1982). Bacteria for studies of the 'switch-off' effect in vivo were grown at $30^{\circ} \mathrm{C}$ in a 1.5 litre Biolafitte fermenter (Poissy, France) containing 1 litre of LSO medium as described by Elmerich et al. (1983). Bacteria for purification of nitrogenase were grown in a 20 litre Chemap fermenter (Zürich, Switzerland) containing 15 litres of LSO medium inoculated to an $\mathrm{OD}_{570}$ of 0.3 with exponentially growing bacteria in YLS medium under air. The $\mathrm{pH}$ was maintained at 7.0 by the addition of $10 \mathrm{M}-\mathrm{HCl}$. The concentration of dissolved $\mathrm{O}_{2}$ was maintained at about $15 \mu \mathrm{M}$ (see Results). Bacteria were harvested under argon after $22 \mathrm{~h}\left(\mathrm{OD}_{570} 3.5\right)$ in a cooled Sharples centrifuge. The paste (about $50 \mathrm{~g}$, wet weight) was frozen and stored in liquid nitrogen until use. For enzymic studies of nitrogenase isolated from 'switched-off' organisms, the same procedure was used but $\left(\mathrm{NH}_{4}\right)_{2} \mathrm{SO}_{4}$ was added at $10 \mathrm{mM}$ final concentration to the growing culture $1 \mathrm{~h}$ before centrifugation.

Assay of nitrogenase activity. Nitrogenase activity was measured either in whole cells or in crude extracts by acetylene reduction; the ethylene produced was determined in an Intersmat IGC $120 \mathrm{FB}$ gas chromatograph (Delsi Instruments, Suresnes, France) fitted with a flame ionization detector. Gas samples $(0.25 \mathrm{ml})$ were injected into a $40 \times 0.2 \mathrm{~cm}$ Porapak T column at $55^{\circ} \mathrm{C}$ with $\mathrm{N}_{2}$ as carrier at a flow rate of $20 \mathrm{ml} \mathrm{min}{ }^{-1}$. With whole cells, a suspension of exponentially $\mathrm{N}_{2}$-growing bacteria in LSO medium was directly injected into a $50 \mathrm{ml}$ rubber-sealed Erlenmeyer flask containing LSO medium and filled with $\mathrm{Ar} / \mathrm{O}_{2}(97: 3, \mathrm{v} / \mathrm{v})$. The final volume was $10 \mathrm{ml}$ and the final $\mathrm{OD}_{570}$ was $0 \cdot 3$. Flasks were equilibrated by shaking at $30^{\circ} \mathrm{C}$ for $10 \mathrm{~min}$ and acetylene was injected $(10 \%, \mathrm{v} / \mathrm{v})$ at zero time. With extracts, the technique described by Eady et al. (1972) was used, with minor modifications in the composition of the assay mixture (see Results). Except in time course studies, the reaction was stopped after $10 \mathrm{~min}$ by injecting $0.1 \mathrm{ml} \mathrm{30 \% (w/v)} \mathrm{TCA.} \mathrm{One} \mathrm{unit} \mathrm{(U)} \mathrm{of} \mathrm{activity} \mathrm{was} \mathrm{defined} \mathrm{as} 1 \mathrm{nmol}$ ethylene produced $\min ^{-1}$. Hydrogen evolution was measured under the same conditions as acetylene reduction, except that the gas phase was Ar alone. Hydrogen formed was determined in a Girdel series-30 gas chromatograph (Delsi Instruments) fitted with a thermal conductivity detector. Gas samples $(0.4 \mathrm{ml})$ were injected into a $2.0 \mathrm{~m} \times 0.3 \mathrm{~cm}$ Porapak R column at $60^{\circ} \mathrm{C}$ with Ar as carrier at a flow rate of $45 \mathrm{ml} \mathrm{min}^{-1}$.

Purification procedure. All operations were done at $4{ }^{\circ} \mathrm{C}$ under strictly anaerobic conditions by working under an argon atmosphere, and by using de-aerated buffers containing $1 \mathrm{mM}$-sodium dithionite and $0.65 \mathrm{mM}$-dithiothreitol. In all purification steps by chromatography or gel filtration, fractions were eluted with an upward flow of buffer driven by a peristaltic pump.

Preparation of crude extract. Frozen cell paste $(10 \mathrm{~g})$ was thawed in $30 \mathrm{ml} 0 \cdot 1 \mathrm{M}-\mathrm{Tris} / \mathrm{HCl}$ buffer $\mathrm{pH} 8 \cdot 0$. Bacteria were disrupted by passage through a French pressure cell at $15000 \mathrm{lbf} \mathrm{in}^{-2}(103.5 \mathrm{MPa})$. The resulting suspension was centrifuged at about $50000 \mathrm{~g}$ for $30 \mathrm{~min}$. The supernatant is referred to as the crude extract.

Separation of nitrogenase components.

Step 1. DEAE-Trisacryl chromatography. The crude extract was adsorbed onto a $8.0 \times 2.5 \mathrm{~cm}$ column of DEAE-Trisacryl (LKB) previously equilibrated with $25 \mathrm{mM}$-Tris/ $\mathrm{HCl}$ buffer $\mathrm{pH} 7 \cdot 4$. The column was washed with one bed volume of buffer before development by stepwise additions of one bed volume each of $0.05 \mathrm{M}$ - and $0.10 \mathrm{M}-\mathrm{NaCl}$, two bed volumes of $0.15 \mathrm{M}-\mathrm{NaCl}$, then two bed volumes of $0.1 \mathrm{M}-\mathrm{MgCl}_{2}$ in the same buffer. The flow rate was approximately $25 \mathrm{ml} \mathrm{h}^{-1}$. Component 1 was eluted as a broad brown band with $0 \cdot 15 \mathrm{M}-\mathrm{NaCl}$. Component 2 was eluted as a brown band with $0 \cdot 1 \mathrm{M}-\mathrm{MgCl}_{2}$. Fractions of about $10 \mathrm{ml}$ were collected and stored as beads in liquid nitrogen. Fractions were tested for activity alone or by complementation with the other component. When assayed alone, a residual activity was found only in fractions containing component 2 .

Step 2. Concentration. Fractions with specific activity greater than $200 \mathrm{U}(\mathrm{mg} \text { protein })^{-1}$ were pooled. Fractions containing component 1 were diluted with an equal volume of $25 \mathrm{mM}$-Tris/HCl buffer $\mathrm{pH} 7 \cdot 4$, adsorbed onto a $4.0 \times 0.9 \mathrm{~cm}$ column of DEAE-Trisacryl and eluted with $0.15 \mathrm{M}-\mathrm{NaCl}$. Fractions containing component 2 were diluted with three volumes of $25 \mathrm{~mm}$-Tris $/ \mathrm{HCl}$ buffer $\mathrm{pH} 7.4$, adsorbed onto a $4.0 \times 0.9 \mathrm{~cm}$ column of DEAE-cellulose (Whatman DE52) and eluted with $0 \cdot 1 \mathrm{M}-\mathrm{MgCl}_{2}$.

Step 3. Gel filtration. Gel filtration of both components was done in $80 \times 0.9 \mathrm{~cm}$ columns, filled with Sephadex G-200 for component 1 and Sephadex G-100 for component 2. Columns were eluted with $25 \mathrm{~mm}-\mathrm{Tris} / \mathrm{HCl}$ buffer $\mathrm{pH} 7 \cdot 4$, at a flow rate of $15 \mathrm{ml} \mathrm{h}^{-1}$.

Protein determination. Protein concentration was assayed by the Coomassie brilliant blue G-250 technique (Sedmak \& Grossberg, 1977) with BSA as a standard.

Gel electrophoresis. SDS-gel electrophoresis was done according to Laemmli \& Favre (1973) with slab gels run at $8 \mathrm{~mA}$ for $18 \mathrm{~h}$. After fixation in $10 \%(\mathrm{w} / \mathrm{v})$ TCA for $1 \mathrm{~h}$, gels were stained with $0.2 \%$ Coomassie blue R-250 in $45: 10: 45(\mathrm{v} / \mathrm{v})$ methanol/acetic acid/water for $2 \mathrm{~h}$ and destained in $15: 7.5: 77 \cdot 5(\mathrm{v} / \mathrm{v}) \mathrm{methanol} / \mathrm{acetic}$ acid/water 
overnight. To determine the $M_{\mathrm{r}}$ of polypeptides, phosphorylase-b (92500), BSA (66200), ovalbumin (45000), carbonic anhydrase $(31000)$ and soybean trypsin inhibitor $(21500)$ were used as standards.

Gel filtration. To determine the $M_{\mathrm{r}}$ of native nitrogenase components, $3.0 \mathrm{mg}$ of each of component 1 and 2 contained in about $1 \mathrm{ml}$ of buffer were chromatographed through Sephadex G-200 $(23 \times 2.6 \mathrm{~cm})$ and Sephacryl S$200(25 \times 2.6 \mathrm{~cm})$ respectively. Protein standards were ferritin $(440000)$, catalase $(232000)$, and aldolase $(158000)$ for component 1 and aldolase, BSA and ovalbumin $\left(M_{\mathrm{r}}\right.$ values given above) for component 2 .

Isoelectric focusing. The basic technique of O'Farrell (1975) was modified according to the LKB 2117 Multiphor operational manual. Ampholines of pH range 3.5-10 (LKB) and 5-8 (Pharmacia) were used. Pre-focusing was done aerobically for $1 \mathrm{~h} \mathrm{at} 15^{\circ} \mathrm{C}$ by maintaining the current at $20 \mathrm{~mA}(200 \mathrm{~W})$. Isoelectric focusing of $5 \mu \mathrm{g}$ samples of pure nitrogenase components 1 and 2 was done under similar conditions for $2 \mathrm{~h}$. After removing ampholines by washing the gels for $1 \mathrm{~h}$ with ethanol/acetic acid/water $60: 5: 35(\mathrm{v} / \mathrm{v})$, proteins were stained by the silver nitrate technique (Merril et al., 1982).

Metal and acid-labile sulphur content. To remove non-specifically bound metal, the protein samples were treated with Chelex 100 (Bio-Rad) according to Eady et al. (1972). Dithionite and dithiothreitol were removed by anaerobic gel filtration through a Sephadex G-10 $(20 \times 1.5 \mathrm{~cm})$ column, equilibrated with a $25 \mathrm{mM}-\mathrm{Tris} / \mathrm{HCl}$ buffer $\mathrm{pH} 7.4$ containing $10 \%(\mathrm{w} / \mathrm{v})$ glycerol. Iron and molybdenum were determined colorimetrically using 4,7diphenyl-1,10-phenanthroline (Doeg \& Ziegler, 1962) and toluene-3,4-dithiol (Bulen \& Le Compte, 1966) respectively. For calibration, an iron standard solution (Sigma) was used. Acid-labile sulphur was determined with $N, N^{\prime}$-dimethyl-p-phenylenediamine by the method of Lovenberg et al. (1963) as modified by Suhara et al. (1975).

\section{RESULTS}

\section{Optimization of culture conditions for nitrogenase biosynthesis}

When Rhizobium strain ORS571 is placed in nitrogen-free medium under microaerobic conditions, nitrogenase activity is derepressed (Elmerich et al., 1982; Dreyfus et al., 1983). For liquid cultures or cultures on solid medium, a $3 \% \mathrm{O}_{2}$ concentration in the gas phase was found to be optimal. For cultures in a fermenter containing 1 litre of medium, with the $\mathrm{pH}$ maintained at $7 \cdot 0$, a 1 litre $\min ^{-1}$ flow of $\mathrm{N}_{2} / \mathrm{O}_{2}(97: 3, \mathrm{v} / \mathrm{v})$ was satisfactory. Scaling up to a 15 litre fermenter, flushed by a 15 litres $\min ^{-1}$ flow of the same gas mixture, led to a lower nitrogenase activity and to less reproducible results. This problem was solved by bubbling the fermenter with a permanent flow of 7 litres $\min ^{-1}$ of $\mathrm{N}_{2} / \mathrm{O}_{2}(97: 3, \mathrm{v} / \mathrm{v})$ and a discontinuous flow of $\mathrm{N}_{2} / \mathrm{O}_{2}(90: 10$, $\mathrm{v} / \mathrm{v}$ ) regulated by an $\mathrm{O}_{2}$ electrode so that the dissolved oxygen concentration in the medium was maintained at about $15 \mu \mathrm{M}$. Under these conditions, a specific activity for nitrogenase of $40 \mathrm{U}$ (mg protein $)^{-1}$ in whole cells was regularly obtained.

\section{Optimization of the assay conditions for nitrogenase activity in crude extracts}

Preparation of active crude extracts required absolute anaerobic conditions. The most active extracts were obtained by disrupting a suspension of bacteria ( $1 \mathrm{~g}$ wet weight bacteria in $3 \mathrm{ml}$ $0.1 \mathrm{M}$-Tris/ $\mathrm{HCl}$ buffer $\mathrm{pH} 8.0$ containing $1 \mathrm{~mm}$-sodium dithionite and $0.65 \mathrm{~mm}$-dithiothreitol) in a French pressure cell. The crude extract (about $14 \mathrm{mg}$ protein $\mathrm{ml}^{-1}$ ) had a $\mathrm{pH}$ of 7.4 . Centrifugation for $30 \mathrm{~min}$ at $50000 \mathrm{~g}$ or for $1 \mathrm{~h}$ at $200000 \mathrm{~g}$ resulted in the same activity in the supernatant. At room temperature, about $60 \%$ of nitrogenase activity was lost after $1 \mathrm{~d}$. For this reason, purification was done at $4{ }^{\circ} \mathrm{C}$, and all the fractions were stored in liquid nitrogen where activity was stable for months.

Acetylene-reducing activity of the crude extract was assayed in $40 \mathrm{mM}-\mathrm{HEPES}$ buffer, $\mathrm{pH} \mathrm{7.4,}$ containing $4 \mathrm{~mm}$-ATP, $8 \mathrm{mM}$-creatine phosphate, $80 \mu \mathrm{g}$ creatine kinase $\mathrm{ml}^{-1}$ and $15 \mathrm{~mm}$-sodium dithionite. Under these conditions, nitrogenase activity had an absolute requirement for $\mathbf{M g}^{2+}$. Maximum activity was obtained with $10 \mathrm{mM}-\mathrm{Mg}^{2+}$. No activity was observed when $\mathbf{M g}^{2+}$ was replaced by $\mathrm{Mn}^{2+}$. The optimum $\mathrm{pH}$ for activity was around $7 \cdot 3$. Under optimum conditions, nitrogenase activity in crude extracts was about $70 \mathrm{U}$ (mg protein) $)^{-1}$.

\section{The nitrogenase components}

Purification. A summary of the purification of the two components of nitrogenase from $10 \mathrm{~g}$ (wet weight) bacteria is given in Table 1 . Both components were purified from the crude extract with a yield of approximately $25 \%$. After purification, neither of the two components had any residual activity when assayed alone. After electrophoresis in SDS-gels, component 1 produced 


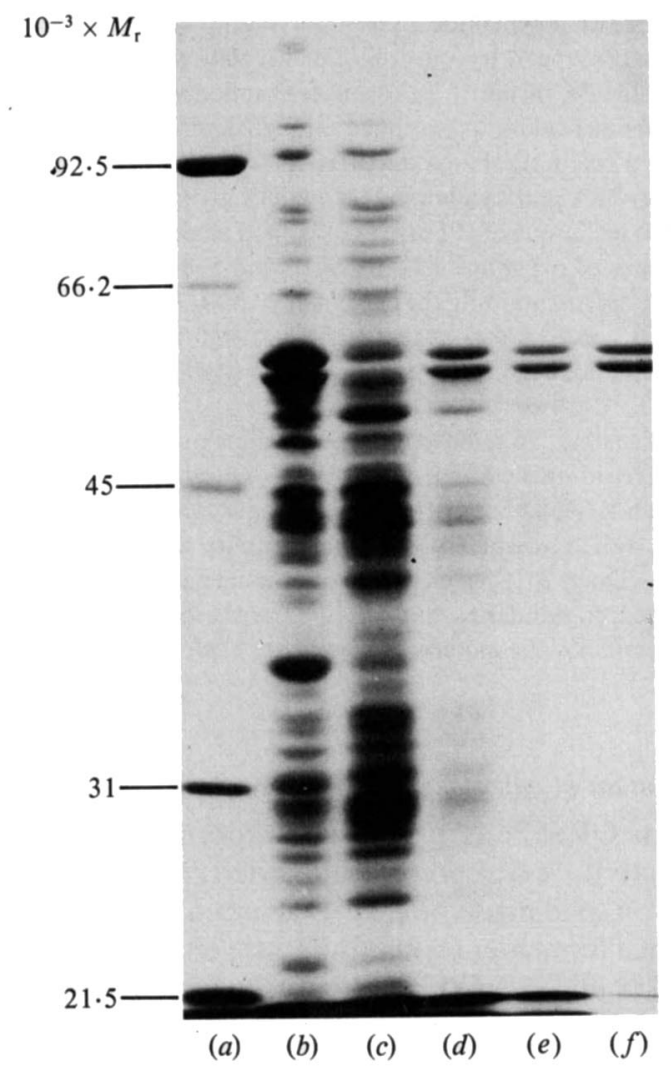

Fig. 1. Electrophoresis of samples containing component 1 of Rhizobium strain ORS571 nitrogenase at each step of purification. Electrophoresis was done on $10 \%$ polyacrylamide gel in the presence of SDS. Lane $(a)$, standard proteins of $M_{\mathrm{r}}$ indicated; lane $(b)$, crude extract of bacteria grown under conditions of $\mathrm{N}_{2}$-fixation (65 $\mu$ g protein); lane (c), crude extract of bacteria grown under conditions of ammoniaassimilation $(67 \mu \mathrm{g}$ protein); lane $(d)$, DEAE-Trisacryl effluent fraction (40 $\mu \mathrm{g}$ protein); lane $(e)$, DEAETrisacryl concentration fraction ( $26 \mu \mathrm{g}$ protein); lane $(f)$, Sephadex G-200 effluent fraction $(10 \mu \mathrm{g}$ protein).

Table 1. Purification of the components of Rhizobium strain ORS571 nitrogenase

\begin{tabular}{|c|c|c|c|c|c|c|}
\hline Step & $\begin{array}{l}\text { Vol. } \\
(\mathrm{ml})\end{array}$ & $\begin{array}{l}\text { Total } \\
\text { activity } \\
\text { (U) }\end{array}$ & $\begin{array}{l}\text { Total } \\
\text { protein } \\
\text { (mg) }\end{array}$ & $\begin{array}{l}\text { Specific activity* } \\
{\left[\mathrm{U}(\mathrm{mg} \text { protein })^{-1}\right]}\end{array}$ & $\begin{array}{l}\text { Purification } \\
\text { factor }\end{array}$ & $\begin{array}{c}\text { Yield } \\
(\%)\end{array}$ \\
\hline Crude extract & 24 & 24400 & 336 & 73 & 1 & 100 \\
\hline $\begin{array}{l}\text { Component } 1 \\
\text { DEAE-Trisacryl effluent } \\
\text { DEAE-Trisacryl concentration } \\
\text { Sephadex G-200 effluent }\end{array}$ & $\begin{array}{r}45 \\
3 \cdot 1 \\
11 \cdot 1\end{array}$ & $\begin{array}{r}17200 \\
13000 \\
5800\end{array}$ & $\begin{array}{l}58 \\
28 \\
4 \cdot 4\end{array}$ & $\begin{array}{r}296 \\
465 \\
1318\end{array}$ & $\begin{array}{c}4 \cdot 1 \\
6 \cdot 3 \\
18\end{array}$ & $\begin{array}{l}70 \\
53 \\
23 \cdot 7\end{array}$ \\
\hline $\begin{array}{l}\text { Component } 2 \\
\text { DEAE-Trisacryl effluent } \\
\text { DEAE-cellulose concentration } \\
\text { Sephadex G-100 effluent }\end{array}$ & $\begin{array}{r}45 \\
6 \\
20\end{array}$ & $\begin{array}{r}21400 \\
18200 \\
6800\end{array}$ & $\begin{array}{l}49 \cdot 5 \\
30 \\
7\end{array}$ & $\begin{array}{l}432 \\
607 \\
971\end{array}$ & $\begin{array}{r}5 \cdot 9 \\
8 \cdot 3 \\
13 \cdot 3\end{array}$ & $\begin{array}{l}87 \cdot 7 \\
74 \cdot 5 \\
27 \cdot 8\end{array}$ \\
\hline
\end{tabular}

* After DEAE-Trisacryl chromatography, the activity was determined by complementation of one component by the other. As titration curves were not established, the specific activity does not necessarily represent the maximum value (see Results). 


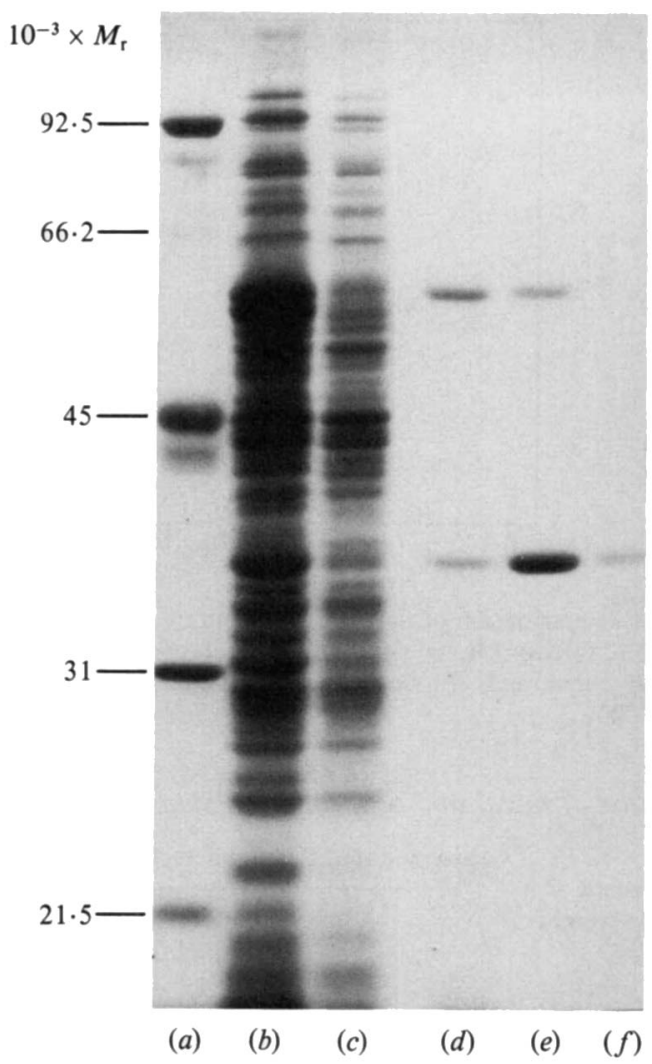

Fig. 2. Electrophoresis of samples containing component 2 of Rhizobium strain ORS571 nitrogenase at each step of purification. Electrophoresis was done on $10 \%$ polyacrylamide gel in the presence of SDS. Lanes $(a),(b)$ and $(c)$, as in Fig. 1; lane $(d)$, DEAE-Trisacryl effluent fraction (37 $\mu$ g protein); lane $(e)$, DEAE-cellulose concentration fraction $(20 \mu \mathrm{g}$ protein); lane $(f)$, Sephadex G-100 effluent fraction (7 $\mu \mathrm{g}$ protein).

two bands of equal intensity and of $M_{\mathrm{r}} 56000$ and 59000 respectively, and component 2 produced a single band of $M_{\mathrm{r}} 36000$ (Figs 1 and 2). It also appears that these bands, present in the crude extracts of bacteria grown under conditions of $\mathrm{N}_{2}$ fixation, are absent from crude extracts of $\mathrm{NH}_{4}^{+}$-repressed organisms (Figs 1 and 2). This was confirmed by immuno-assays with specific antisera against purified components 1 and 2 (results not shown). As previously reported for component 1 of other diazotrophs (Kennedy et al., 1976), resolution of Rhizobium strain ORS571 component 1 into two distinct protein-staining bands depended on the commercial source of the SDS used. Two bands were observed with Koch-Light SDS whereas a single diffuse band was formed with Sigma SDS (results not shown).

Molecular weight of the native components. The $M_{\mathrm{r}}$ determined by gel filtration was 219000 for component 1 and 74000 for component 2 (Fig. 3). This suggests that, as for other nitrogenases, component 1 is a tetramer made up of two different types of subunits $\left(\alpha_{2} \beta_{2}\right)$ and component 2 is a dimer made up of a single type of subunit.

Metal and acid-labile sulphur content. Component 1 contained (mean $\pm \mathrm{SE}$ ) $1 \cdot 16 \pm 0.05 \mathrm{~g}$ atoms $\mathrm{Mo} \mathrm{mol}^{-1}, 22.5 \pm 2.1 \mathrm{~g}$-atoms $\mathrm{Fe} \mathrm{mol}^{-1}$ and $20.5 \pm 1.6 \mathrm{~g}$-atoms acid-labile S mol ${ }^{-1}$, while component 2 contained $3 \cdot 1 \pm 0.4 \mathrm{~g}$-atoms Fe mol ${ }^{-1}, 3 \cdot 1 \pm 0.4 \mathrm{~g}$-atoms acid-labile $\mathrm{S} \mathrm{mol}^{-1}$ and no molybdenum (Table 2). Component 1 thus appears to be a typical Mo-Fe protein and component 2 appears to be a typical $\mathrm{Fe}$ protein of the nitrogenase complex. 


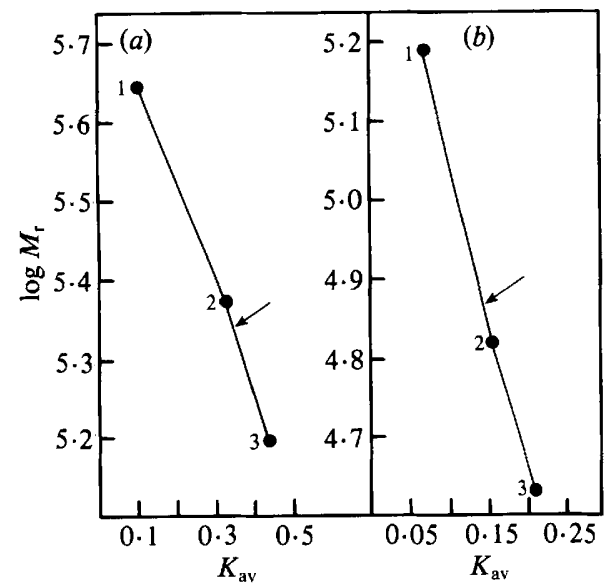

Fig. 3. Molecular weight determination of native components 1 and 2. (a), Component 1 (arrowed). Protein standards were: 1 , ferritin $\left(M_{\mathrm{r}}=440000\right) ; 2$, catalase $\left(M_{\mathrm{r}}=232000\right) ; 3$, aldolase $\left(M_{\mathrm{r}}=\right.$ $158000)$. (b), Component 2 (arrowed). Protein standards were: 1 , aldolase; 2 , BSA $\left(M_{\mathrm{r}}=66200\right)$; 3 , ovalbumin $\left(M_{\mathrm{r}}=45000\right)$.

Table 2. Determination of metal and acid-labile sulphur content of components 1 and 2

\begin{tabular}{|c|c|c|c|}
\hline & & Amount of element detected & \\
\hline & $\begin{array}{l}\text { Protein } \\
\text { sample weight } \\
(\mu \mathrm{g})\end{array}$ & $\begin{array}{c}\text { n-atoms } \\
\text { (mg protein })^{-1}\end{array}$ & $\begin{array}{l}\text { Molar proportion of element* } \\
\left.[\text { mol (mol protein })^{-1}\right]\end{array}$ \\
\hline
\end{tabular}

Component 1

Molybdenum

$\begin{array}{rcc}27 & 5 \cdot 11 & 1 \cdot 12 \\ 60 & 5 \cdot 68 & 1 \cdot 24 \\ 109 & 5 \cdot 16 & 1 \cdot 13 \\ 332 & 108 \cdot 0 & 23 \cdot 6 \\ 651 & 105 \cdot 9 & 23 \cdot 2 \\ 1170 & 95 \cdot 2 & 20 \cdot 8 \\ 175 & 99 \cdot 2 & 21 \cdot 7 \\ 325 & 92 \cdot 1 & 20 \cdot 2 \\ 627 & 88 \cdot 9 & 19 \cdot 5\end{array}$

Component 2

Molybdenum

Iron

$100 \quad<2$

$50 \quad 125$

$100 \quad 225$

$200 \quad 462$

Acid-labile sulphur

$\begin{array}{rr}50 & 70 \\ 100 & 125\end{array}$

200

$\begin{array}{ll}44 \cdot 8 & 3 \cdot 31 \\ 40.3 & 2 \cdot 98 \\ 41 \cdot 4 & 3 \cdot 06 \\ 43 \cdot 7 & 3 \cdot 23 \\ 39 \cdot 0 & 2 \cdot 89 \\ 41 \cdot 3 & 3.06\end{array}$

${ }^{*} M_{\mathrm{r}}$ was estimated as 219000 for component 1 and 74000 for component 2 .

Isoelectric point. When samples $(5 \mu \mathrm{g})$ of components 1 and 2 were subjected to isoelectric focusing, single bands revealed by the silver nitrate technique were observed in both cases with pI values of 6.9 and $5 \cdot 3$ respectively.

Specific activity. The activity titration of component 2 with component 1 is shown in Fig. $4(a)$. Addition of increasing amounts of component 1 to a fixed amount $(21 \mu \mathrm{g})$ of component 2 resulted in an almost linear increase of nitrogenase activity up to a maximum followed by a slight decrease. The maximum was reached at a ratio of $60 \mu \mathrm{g}$ component 1 to $21 \mu \mathrm{g}$ component 2 . Taking the $M_{\mathrm{r}}$ values to be 219000 and 74000 respectively, this corresponds to a component $1 /$ component 2 molecular ratio of $1: 1.04$. Under these conditions, the specific activity of component 2 was $1700 \mathrm{U}$ (mg protein $)^{-1}$. 


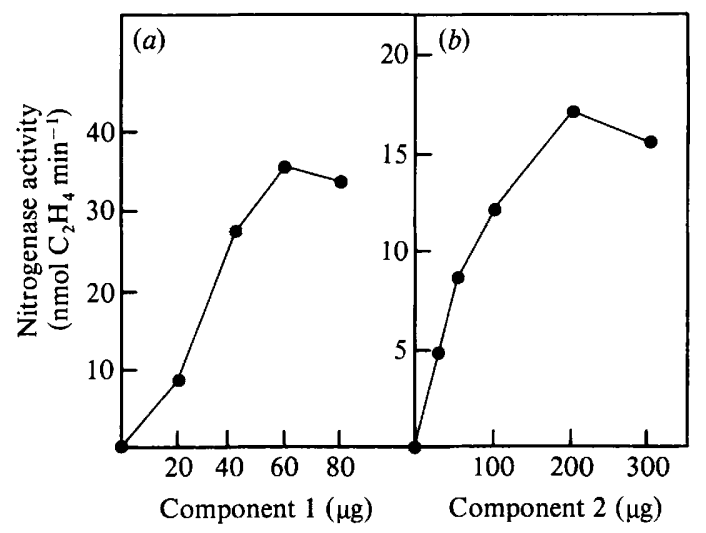

Fig. 4. Influence of nitrogenase component ratio on enzyme activity. (a), Titration of component 2 $(21 \mu \mathrm{g})$ with component 1 ; (b), titration of component $1(14 \mu \mathrm{g})$ with component 2.

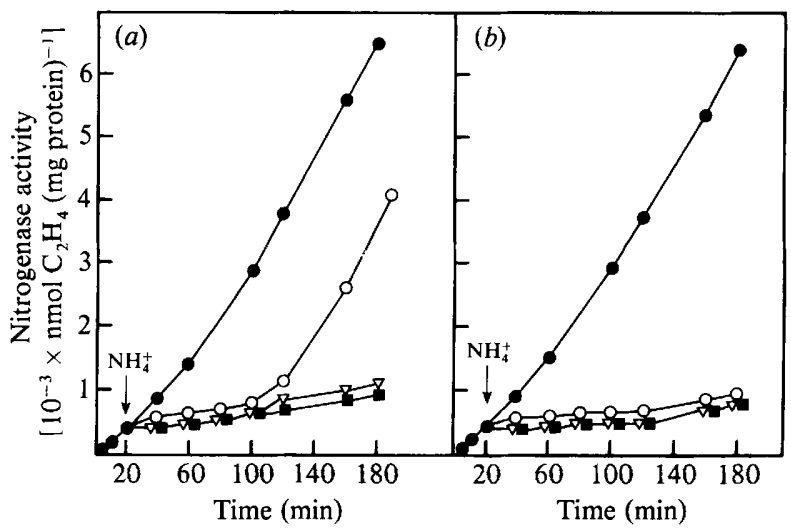

Fig. 5. Effect of ammonia shock on nitrogenase activity in vivo. (a), Activity in the absence of chloramphenicol; $(b)$, activity in the presence of chloramphenicol $\left(50 \mu \mathrm{g} \mathrm{ml}^{-1}\right)$. After $20 \mathrm{~min}$, ammonium sulphate was added to $10 \mathrm{ml}$ bacterial suspension $\left(\mathrm{OD}_{570} 0 \cdot 3\right)$ in LSO medium to give a final $\mathrm{NH}_{4}^{+}$concentration of $0.1 \mathrm{~mm}(\mathrm{O}), 1 \mathrm{~mm}(\nabla)$ or $10 \mathrm{~mm}(\boldsymbol{C})$. No $\mathrm{NH}_{4}^{+}$addded.

Titration of component 1 with component 2 is shown in Fig. 4(b). The maximum activity was reached at a ratio of $14 \mu \mathrm{g}$ component 1 to $200 \mu \mathrm{g}$ component 2 . This corresponds to a component $1 /$ component 2 molecular ratio of $1: 42$. Under these conditions, the specific activity of component 1 was $1250 \mathrm{U}$ (mg protein $)^{-1}$.

Hydrogen evolution was measured with crude extracts and purified components. In both cases, hydrogen production was ATP-dependent. The specific activity of the crude extract was $79 \mathrm{nmol} \mathrm{H}_{2}$ formed $\min ^{-1}$ (mg protein) $)^{-1}$. Titration curves were not established with purified components, but it was assumed that maximum activity was reached at the same component ratios as for $\mathrm{C}_{2} \mathrm{H}_{4}$ production. The specific activity of component 1 , in the presence of a 40 -fold molar excess of component 2, was $1090 \mathrm{nmol} \mathrm{H}_{2}$ formed $\min ^{-1}$ (mg protein) ${ }^{-1}$; the specific activity of component 2 , in the presence of an equimolar concentration of component 1 , was $1300 \mathrm{nmol} \mathrm{H}_{2}$ formed $\min ^{-1}$ (mg protein) $)^{-1}$. As expected, components 1 and 2 had no $\mathrm{H}_{2^{-}}$ evolving activity when assayed alone.

\section{The ammonia 'switch-off' of nitrogenase}

Studies with whole cells. The addition of $\mathrm{NH}_{4}^{+}$to $\mathrm{N}_{2}$-fixing cultures resulted in a rapid and almost total inhibition of nitrogenase activity (Fig. 5). Inhibition occurred both in the presence and in the absence of $50 \mu \mathrm{g}$ chloramphenicol ml ${ }^{-1}$. When the $\mathrm{NH}_{4}^{+}$concentration was $0 \cdot 1 \mathrm{mM}$ or 
Table 3. Purification of the components of $\mathrm{N}_{2}$ ase $R$ of Rhizobium strain ORS571

\begin{tabular}{lcccc}
\multicolumn{1}{c}{ Step } & $\begin{array}{c}\text { Vol. } \\
(\mathrm{ml})\end{array}$ & $\begin{array}{c}\text { Total activity } \\
(\mathrm{U})\end{array}$ & $\begin{array}{c}\text { Total protein } \\
(\mathrm{mg})\end{array}$ & $\begin{array}{c}\text { Specific activity* } \\
{\left[\mathbf{U} \text { (mg protein) }^{-1} \text { ] }\right.}\end{array}$ \\
Crude extract & 30 & 3300 & 390 & 8.5 \\
Component 1 & & & & 269 \\
DEAE-Trisacryl effluent & 45 & 19650 & 73 & 421 \\
DEAE-Trisacryl concentration & $2 \cdot 5$ & 10945 & 26 & 830 \\
Sephadex G-200 effluent & 20 & 4980 & 6.0 & 78 \\
Component 2 & & & & 117 \\
DEAE-Trisacryl effluent & 55 & 4290 & 55 & 258 \\
DEAE-cellulose concentration & $3 \cdot 4$ & 3635 & 31 & 6
\end{tabular}

* After DEAE-Trisacryl chromatography, the activity was determined by complementation with pure components of $\mathrm{N}_{2}$ ase A. As titration curves were not established the specific activity does not necessarily represent the maximum value (see Results).

lower (results not shown), nitrogenase activity in cells not treated with chloramphenicol reappeared after a period of inhibition (Fig. $5 a$ ). This phenomenon did not occur when chloramphenicol was present (Fig. $5 b$ ).

The addition of glutamine $(0.1$ to $10 \mathrm{mM})$ resulted in a $70 \%$ inhibition of nitrogenase activity. Surprisingly glutamate $(0 \cdot 1$ to $10 \mathrm{mM})$, although a good $\mathrm{N}$ source for strain ORS571, did not inhibit activity.

The nitrogenase of ammonia-shocked bacteria. The inhibitory effect of $\mathrm{NH}_{4}^{+}$on nitrogenase activity in vivo was reminiscent of the 'switch-off/on' effect first described, and now well documented, in photosynthetic bacteria (see e.g. Ludden et al., 1984). We therefore decided to adopt the same terminology and to call the enzyme present in $\mathrm{N}_{2}$-growing cells $\mathrm{N}_{2}$ ase $A$, and the enzyme present in ammonia-shocked cells $\mathrm{N}_{2}$ ase $\mathrm{R}$.

Studies with crude extracts. Under standard assay conditions, the $\mathrm{N}_{2}$ ase $\mathrm{R}$ activity in crude extracts was between 1 and $10 \%$ of that found for $\mathrm{N}_{2}$ ase A. The 'activating conditions' (Ludden \& Burris, 1976; Hallenbeck et al., 1982), which restore activity to $\mathrm{N}_{2}$ ase $\mathrm{R}$ of photosynthetic bacteria and include addition of $\mathrm{Mn}^{2+}$ to the reaction mixture of the $\mathrm{N}_{2}$ ase $\mathrm{R}$ assay, were tested. Concentrations of $\mathrm{Mn}^{2+}$ ranging from 0.1 to $0.5 \mathrm{mM}$ were added to reaction mixtures containing 5,10 or $20 \mathrm{~mm}-\mathrm{Mg}^{2+}$. Such additions did not modify the activity of $\mathrm{N}_{2}$ ase A (results not shown); neither was activation of $\mathrm{N}_{2}$ ase $\mathrm{R}$ observed. In contrast to photosynthetic bacteria (Gotto \& Yoch, 1982a), the addition of extracts of ammonia-grown cells also failed to elicit activation.

Purification and properties of components 1 and 2 of $\mathrm{N}_{2}$ ase $R$. The same purification procedure as that described in Table 1 for $\mathrm{N}_{2}$ ase $A$ was applied to a crude extract containing $\mathrm{N}_{2}$ ase $\mathrm{R}$ : both components were purified with approximately the same protein yield as the components of $\mathrm{N}_{2}$ ase A (Table 3). They were homogeneous as judged by SDS electrophoresis, and the $M_{\mathrm{r}}$ values of their subunits did not differ significantly from those of $\mathrm{N}_{2}$ ase A (Fig. 6). However, it appears from Table 3 that, as in photosynthetic bacteria, component 2 was impaired in its activity. This was confirmed by titration studies (Figs 7 and 8 ).

When $\mathrm{N}_{2}$ ase $\mathrm{R}$ component 2 was titrated with component 1 isolated from $\mathrm{N}_{2}$ ase $A$ or $\mathrm{N}_{2}$ ase $\mathrm{R}$ (Fig. 7), approximately the same maximum activity was reached at the same molar ratio. The maximum specific activity of $\mathrm{N}_{2}$ ase $\mathrm{R}$ component 2 was $286 \mathrm{U}$ (mg protein) ${ }^{-1}$ when titrated with $\mathrm{N}_{2}$ ase A component 1 , and $270 \mathrm{U}$ (mg protein) ${ }^{-1}$ when titrated with $\mathrm{N}_{2}$ ase $\mathrm{R}$ component 1 . Taking the same $M_{\mathrm{r}}$ for components 1 and 2 of $\mathrm{N}_{2}$ ase A and R (Fig. 6), it appears from Fig. 7 that the maximum activity was reached in both cases for a component 1 /component 2 molar ratio of about $1: 10$.

When $\mathrm{N}_{2}$ ase $\mathrm{R}$ component 1 was titrated with component 2 isolated from $\mathrm{N}_{2}$ ase $A$ or $\mathrm{N}_{2}$ ase $\mathrm{R}$ (Fig. 8), maximum activity was similar in both cases but the amount of component 2 required to reach the maximum was four-fold higher when it originated from $\mathrm{N}_{2}$ ase $R$ than from $\mathrm{N}_{2}$ ase $A$. 


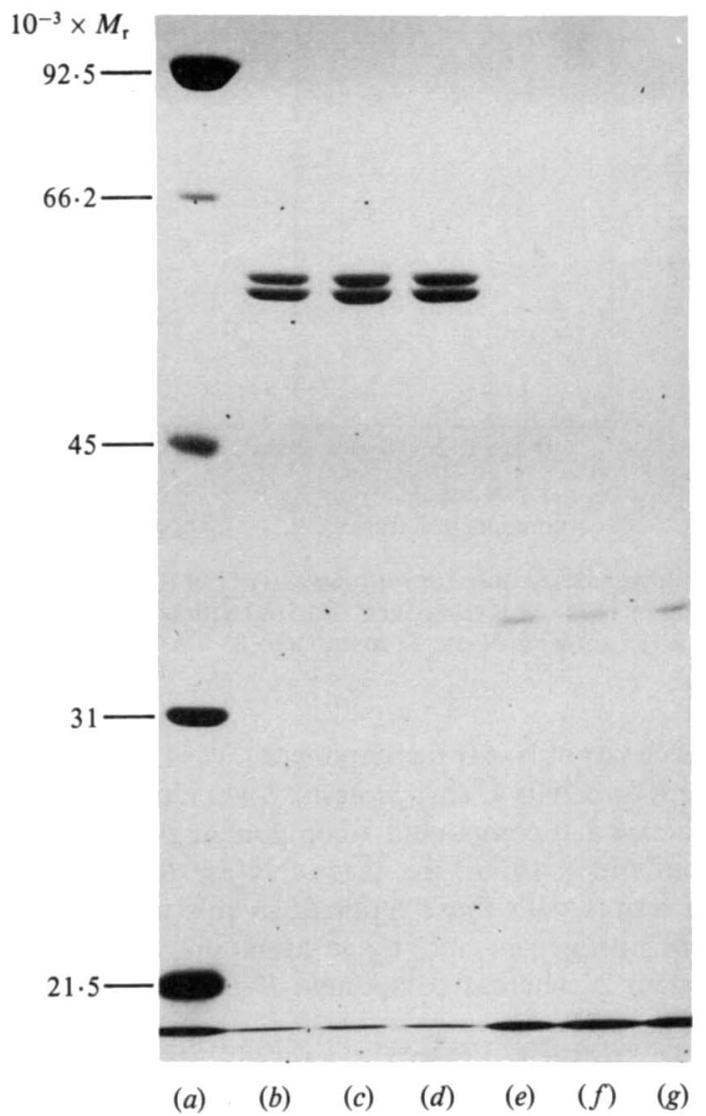

Fig. 6. Comparison of electrophoretic patterns of pure components 1 and 2 of $\mathrm{N}_{2}$ ase $A$ and $\mathrm{N}_{2}$ ase $R$ of Rhizobium strain ORS571. Electrophoresis was done on $10 \%$ polyacrylamide gel in the presence of SDS. Lane (a), standard proteins of $M_{\mathrm{r}}$ indicated; lane (b), $\mathrm{N}_{2}$ ase A component $1(7 \mu \mathrm{g})$; lane $(c), \mathrm{N}_{2}$ ase $\mathrm{R}$ component $\mathrm{I}(8 \mu \mathrm{g}) ;$ lane $(d), \mathrm{N}_{2}$ ase A component $1(3.5 \mu \mathrm{g})$ and $\mathrm{N}_{2}$ ase $\mathrm{R}$ component $1(4 \mu \mathrm{g})$; lane $(e)$, $\mathrm{N}_{2}$ ase A component $2(5 \mu \mathrm{g})$; lane $(f), \mathrm{N}_{2}$ ase R component $2(6 \mu \mathrm{g})$; lane $(\mathrm{g}), \mathrm{N}_{2}$ ase A component 2 $(2 \cdot 5 \mu \mathrm{g})$ and $\mathrm{N}_{2}$ ase $\mathrm{R}$ component $2(3 \mu \mathrm{g})$.

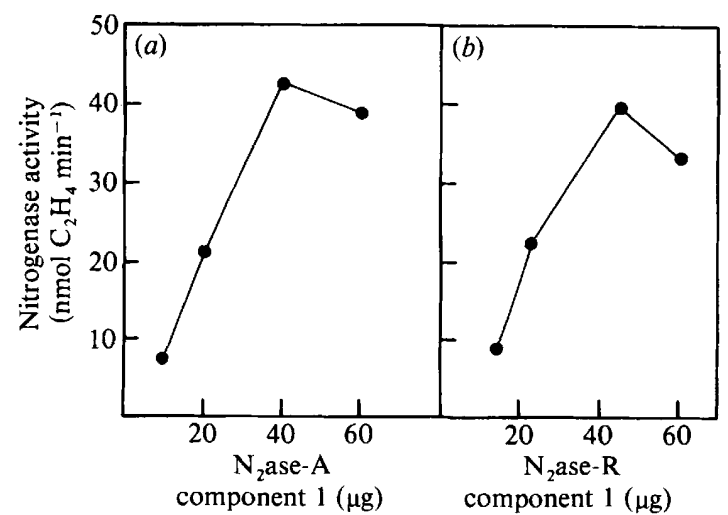

Fig. 7. Influence of nitrogenase component ratio on activity of a complex containing nitrogenase $\mathbf{R}$ component 2. (a), Titration of $\mathrm{N}_{2}$ ase $\mathrm{R}$ component $2(150 \mu \mathrm{g})$ with $\mathrm{N}_{2}$ ase A component 1 ; (b), titration of $\mathrm{N}_{2}$ ase $\mathrm{R}$ component $2(150 \mu \mathrm{g})$ with $\mathrm{N}_{2}$ ase $\mathrm{R}$ component 1 . 


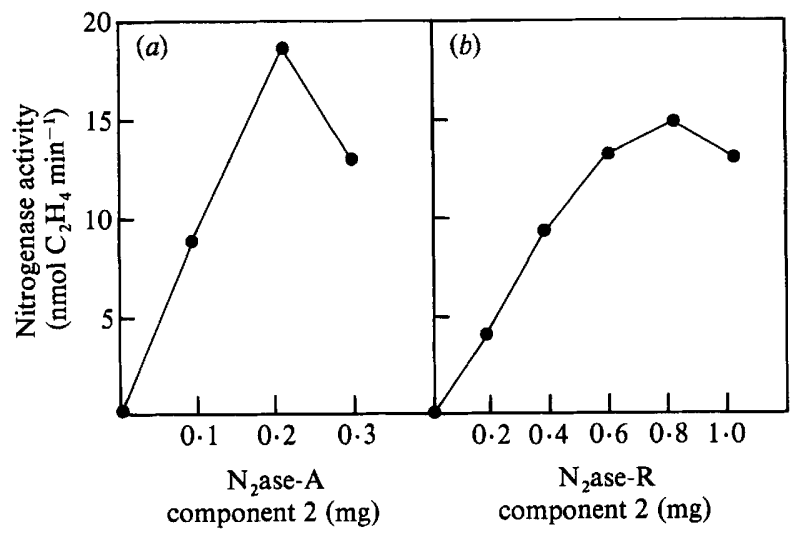

Fig. 8. Influence of nitrogenase component ratio on activity of a complex containing nitrogenase $\mathbf{R}$ component 1. (a), Titration of $\mathrm{N}_{2}$ ase $\mathrm{R}$ component 1 (15 $\left.\mu \mathrm{g}\right)$ with $\mathrm{N}_{2}$ ase A component $2 ;(b)$, titration of $\mathrm{N}_{2}$ ase $\mathrm{R}$ component $1(15 \mu \mathrm{g})$ with $\mathrm{N}_{2}$ ase $\mathrm{R}$ component 2 .

The maximum specific activity of $\mathrm{N}_{2}$ ase $\mathrm{R}$ component 1 was $1144 \mathrm{U}$ (mg protein) $)^{-1}$ when titrated with $\mathrm{N}_{2}$ ase A component 2 and $995 \mathrm{U}$ (mg protein) ${ }^{-1}$ when titrated with $\mathrm{N}_{2}$ ase $\mathrm{R}$ component 2 . This maximum was reached at a component 1/component 2 molar ratio of $1: 41$ when $\mathrm{N}_{2}$ ase $\mathrm{A}$ component 2 was added and $1: 162$ in the case of $\mathrm{N}_{2}$ ase $\mathrm{R}$ component 2 .

By comparing these results with those reported in this paper for $\mathrm{N}_{2}$ ase A components, it appears that the loss of nitrogenase activity in ammonia-shocked cells was due to a strong inactivation of component 2 , whereas component 1 remained fully active.

\section{DISCUSSION}

The purified nitrogenase components of Sesbania Rhizobium strain ORS571 grown in the freeliving state have very similar physicochemical properties to previously characterized nitrogenases (Eady \& Smith, 1979).

The Mo-Fe protein is a tetramer of $M_{\mathrm{r}} 219000$ made up of two different subunits of $M_{\mathrm{r}} 56000$ and 59000 respectively. Early reports on the Mo-Fe protein of $R$. japonicum (Israel et al., 1974) and $R$. lupini (Whiting \& Dilworth, 1974) have described the protein as made up of a single type of subunit. Further studies showed that this finding was due to the commercial source of SDS used (Kennedy et al., 1976). In addition, the existence of two types of subunits is in agreement with the characterization of genes equivalent to nif $K$ and nifD in all diazotrophs which have been studied (see e.g. Robson et al., 1983) including strain ORS571 (Elmerich et al., 1982 and this laboratory unpublished). The Mo-content of about $1 \mathrm{~g}$-atom $\mathrm{mol}^{-1}$ is in agreement with many values reported (Eady \& Smith, 1979). However the most active preparations from Clostridium pasteurianum and Klebsiella pneumoniae have been shown to contain $2 \mathrm{~g}$-atoms $\mathrm{mol}^{-1}$ (Eady \& Smith, 1979) and it is possible that, as in other cases, our preparation was contaminated by inactive protein lacking molybdenum. The iron and acid-labile sulphur content of about $20 \mathrm{~g}-$ atoms $\mathrm{mol}^{-1}$ is also compatible with other values reported (Eady \& Smith, 1979). The pI of 6.9 is higher than that of $K$. pneumoniae Mo-Fe protein (Eady et al., 1972). This is in agreement with the fact that the enzyme is eluted from a DEAE ion-exchanger at a lower concentration of $\mathrm{NaCl}$ $(0.15 \mathrm{M}$ instead of $0.23 \mathrm{M})$.

The Fe protein is a dimer of $M_{\mathrm{r}} 74000$ made of a single type of subunit. The iron and acidlabile sulphur content is closer to 3 than to $4 \mathrm{~g}$-atoms $\mathrm{mol}^{-1}$, the usual value found for other $\mathrm{Fe}$ proteins (Eady \& Smith 1979). This may be due to contamination of the preparation by an inactive fraction.

Titration of the Mo-Fe protein with the Fe protein and vice versa gave results similar to those found with other nitrogenase components (e.g. see Eady et al., 1972; Hallenbeck et al., 1982). A 
maximum activity of 1250 units (mg Mo-Fe protein) ${ }^{-1}$ was found in the presence of a 42 -fold molar excess of $\mathrm{Fe}$ protein, whereas a maximum activity of 1700 units (mg Fe protein $)^{-1}$ was found in the presence of an equimolar concentration of Mo-Fe protein. As observed with other nitrogenases, e.g. K. pneumoniae (Eady et al., 1972), the specific activity of components 1 and 2 for ATP-dependent $\mathrm{H}_{2}$ production was of the same order of magnitude as for acetylene reduction. However, in contrast to $K$. pneumoniae nitrogenase, the specific activity of which is a little higher for $\mathrm{H}_{2}$ evolution than for $\mathrm{C}_{2} \mathrm{H}_{2}$ reduction, the opposite situation was observed with Rhizobium ORS571 nitrogenase, particularly with component 2 . Further studies are required to confirm that the values obtained, 1300 and 1700 for $\mathrm{H}_{2}$ production and acetylene reduction respectively, are significantly different and reflect specific features of the Fe protein.

Nitrogenase activity had an absolute requirement for $\mathrm{Mg}^{2+}$; no residual activity was observed when $\mathrm{Mg}^{2+}$ was replaced by $\mathrm{Mn}^{2+}$ in contrast to other nitrogenases, e.g. K. pneumoniae nitrogenase (Eady et al., 1972). Both the Mo-Fe protein and the Fe protein, either purified or in crude extracts were highly sensitive to inactivation by oxygen. Their instability when stored under anaerobic conditions at room temperature is unusual for nitrogenase preparations and necessitated their purification at $4{ }^{\circ} \mathrm{C}$; however they could be stored for months in liquid nitrogen.

The absence of Mo-Fe protein and Fe protein in ammonia-grown cells suggests that their biosynthesis is repressed under these conditions, as is the case in all other nitrogenases studied. Regulation by oxygen was not examined in detail but no activity was detected in bacteria placed in a nitrogen-free medium in the presence of air. Gebhardt et al. (1984) reported that nitrogenase activity of Rhizobium strain ORS571 was strongly decreased when the bacteria were grown at dissolved $\mathrm{O}_{2}$ levels above $9 \mu \mathrm{M}$. This result differs appreciably from our observations which showed that both maximum growth rate (about $6 \mathrm{~h}$ division time) and maximum nitrogenase activity were obtained at a dissolved $\mathrm{O}_{2}$ concentration around $15 \mu \mathrm{M}$. It is possible that this apparent discrepancy is due to our use of batch cultures whereas Gebhardt et al. (1984) used continuous cultures at dilution rates of $0 \cdot 1$ or less. As there is apparently no specific system for protection of nitrogenase inactivation by $\mathrm{O}_{2}$ in strain ORS571, the reduction of the metabolic rate in a chemostat may result in a greater sensitivity of nitrogenase to $\mathrm{O}_{2}$. However, when strain ORS571 was grown under our optimum conditions, the specific activity of nitrogenase, $40 \mathrm{U}$ (mg protein) ${ }^{-1}$ in whole cells and $70 \mathrm{U}$ (mg protein) ${ }^{-1}$ in crude extracts, was similar to values obtained with the most efficient free-living diazotrophs.

The addition of $\mathrm{NH}_{4}^{+}$to $10 \mathrm{ml}$ samples or to a 15 litre fermenter culture of $\mathrm{N}_{2}$-growing cells resulted in an immediate and practically total inhibition of nitrogenase activity in vivo and in crude extracts. As in the 'switch-off/on' effect which exists in photosynthetic bacteria (see e.g. Ludden et al., 1984) the inhibition of nitrogenase in the presence of chloramphenicol (Fig. 5) suggests that the phenomenon is independent of protein synthesis. In addition, the phenomenon is also reversible since nitrogenase activity reappeared after 100 min when the $\mathrm{NH}_{4}^{+}$inhibitory concentration was $0.1 \mathrm{mM}$ (Fig. $5 a$ ) or earlier for lower concentrations (results not shown). In the presence of chloramphenicol (Fig. $5 b$ ) it is likely that nitrogenase activity did not reappear because the antibiotic, by preventing protein synthesis, also prevented the exhaustion of ammonia in the medium. It cannot be totally excluded, however, that protein synthesis is necessary to restore activity.

In photosynthetic bacteria, the Fe protein is inactivated by attachment of a modifying group consisting of phosphate, pentose and an adenine-like moiety (Ludden \& Burris, 1978). Whereas the active $\mathrm{Fe}$ protein consists of two identical subunits of $M_{\mathrm{r}} 30000$, the inactive form consists of two different subunits migrating in SDS-gels as two bands of $M_{\mathrm{r}} 30000$ and 31500 (Gotto \& Yoch, $1982 b$; Ludden et al., 1982). An $\mathrm{O}_{2}$-sensitive membrane-bound activating enzyme that requires $\mathrm{Mn}^{2+}$ for activity has been shown to remove the modifying group (Ludden \& Burris, 1976; Hallenbeck et al., 1982). This enzyme is present in cells grown on any nitrogen source, even ammonia (Gotto \& Yoch, 1982a). In strain ORS571, $\mathrm{NH}_{4}^{+}$'switch-off' results in a specific inactivation of the Fe protein from $1700 \mathrm{U}$ (mg protein) $)^{-1}$ in $\mathrm{N}_{2}$ ase $\mathrm{A}$ to $280 \mathrm{U}$ (mg protein) ${ }^{-1}$ in $\mathrm{N}_{2}$ ase R. In contrast to Rhodospirillum rubrum (Gotto \& Yoch, 1982b; Ludden et al., 1982), SDS-gel electrophoresis failed to resolve the inactive Fe protein of strain ORS571 into two bands 
(Fig. 6). This might be an artefact, or modification of the Fe protein might be different from that observed in photosynthetic bacteria and so be undetectable by this method.

Attempts to reactivate $\mathrm{N}_{2}$ ase $\mathrm{R}$ of strain ORS571 in vitro are still too preliminary to be discussed in detail. It is, however, worth noting that the lack of response to $\mathrm{Mn}^{2+}$ in $\mathrm{N}_{2}$ ase $\mathrm{R}$ containing crude extracts contrasts with the situation in photosynthetic bacteria.

To our knowledge, this is the first documented report of the existence of a $\mathrm{NH}_{4}^{+}$'switch off' effect in a Rhizobium strain. Whatever the mechanism, one may speculate that this control of nitrogenase activity also occurs when strain ORS571 is living in symbiosis with the host plant, and may also be a general property of rhizobia.

The authors wish to thank Dr R. R. Eady for stimulating discussions while this work was in progress and for improving the manuscript. This study was supported by a scholarship of the French Government to A.K., by a grant [no. GB1-5-028F (SD)] from the Commission of the European Communities and by research funds from the University Paris 7.

\section{REFERENCES}

Bulen, W. A. \& Le Compte, J. R. (1966). The nitrogenase system from Azotobacter: two-enzyme requirement for $\mathrm{N}_{2}$ reduction, ATP-dependent $\mathrm{H}_{2}$ evolution and ATP-hydrolysis. Proceedings of the National Academy of Sciences of the United States of America 56, 979-986.

DoEG, K. A. \& ZIEGleR, D. M. (1962). Simplified methods for the estimation of iron in mitochondria and submitochondrial fractions. Archives of Biochemistry and Biophysics 97, 37-40.

DReYfus, B. L. \& DOMmergues, Y. R. (1981). Nitrogen fixing nodules induced by Rhizobium on the stem of the tropical legume Sesbania rostrata. FEMS Microbiology Letters 10, 313-317.

Dreyfus, B. L., Elmerich, C. \& Dommergues, Y. R. (1983). Free living Rhizobium strain able to grow on $\mathrm{N}_{2}$ as the sole nitrogen source. Applied and Environmental Microbiology 45, 711-713.

EADY, R. R. \& SMITH, B. E. (1979). Physico-chemical properties of nitrogenase and its components. In $A$ Treatise on Dinitrogen Fixation, sections I and II, pp. 399-490. Edited by R. W. F. Hardy, F. Bottomley \& R. C. Burns. New York: J. Wiley \& Sons.

Eady, R. R., Smith, B. E., CoOK, K. A. \& Postgate, J. R. (1972). Nitrogenase of Klebsiella pneumoniae. Purification and properties of the component proteins. Biochemical Journal 128, 655-675.

Elmerich, C., Dreyfus, B. L., Reysset, G. \& Aubert, J.-P. (1982). Genetic analysis of nitrogen fixation in a tropical fast-growing Rhizobium. EMBO Journal 1, 499-503.

Elmerich, C., Dreyfus, B. \& Aubert, J.-P. (1983). Nicotinic acid requirement and degradation by Sesbania Rhizobium strain ORS571. FEMS Microbiology Letters 19, 281-284.

Gebhardt, C., Turner, G. L., Gibson, A. H., DREYFus, B. L. \& Bergersen, F. J. (1984). Nitrogen-fixing growth in continuous culture of a strain of Rhizobium sp. isolated from stem nodules of Sesbania rostrata. Journal of General Microbiology 130, 843-848.

Gotro, W. J. \& Yoch, D. C. (1982a). Purification and $\mathrm{Mn}^{2+}$ activation of Rhodospirillum rubrum nitrogenase activating enzyme. Journal of Bacteriology 152 , 714-721.

GotTo, J. W. \& YосH, D. C. (1982b). Regulation of
Rhodospirillum rubrum nitrogenase activity: properties and interconversion of active and inactive $\mathrm{Fe}$ protein. Journal of Biological Chemistry 257, 28682873.

Hallenbeck, P. C., Meyer, C. M. \& Vignais, P. M. (1982). Regulation of nitrogenase in the photosynthetic bacterium Rhodopseudomonas capsulata as studied by two-dimensional gel electrophoresis. Journal of Bacteriology 149, 708-717.

ISRAEL, D. W., HowaRD, R. L., Evans, J. \& Russel, S. A. (1974). Purification and characterization of the molybdenum-iron protein component of nitrogenase from soybean nodule bacteroids. Journal of Biological Chemistry 249, 500-508.

KenNedy, C., EADY, R. R., Kondorosi, E. \& ReKosh, D. K. (1976). The molybdenum-iron protein of Klebsiella pneumoniae nitrogenase. Evidence for nonidentical sub-units from peptide "mapping". Biochemical Journal 155, 383-389.

LAEMML1, U. K. \& FAVRE, M. (1973). Maturation of the head of bacteriophage T-4. 1. DNA packaging events. Journal of Molecular Biology 80, 575-599.

LOVENBERG, W., Buchanan, B. B. S. \& Rabinowitz, J. C. (1963). Studies on the chemical nature of clostridial ferredoxin. Journal of Biological Chemistry 238, 3899-3913.

LudDEN, P. W. \& BURRIS, R. H. (1976). Activating factor for the iron-protein of nitrogenase from Rhodospirillum rubrum. Science 194, 424-426.

Ludden, P. W. \& BurRis, R. H. (1978). Purification and properties of nitrogenase from Rhodospirillum rubrum and evidence for phosphate, ribose and an adenine-like unit covalently bound to the ironprotein. Biochemical Journal 175, 251-259.

Ludden, P. W., Preston, G. G. \& Dowling, T. E. (1982). Comparison of active and inactive forms of the iron-protein from Rhodospirillum rubrum. Biochemical Journal 203, 663-668.

Ludden, P. W., Murrel, S. A., Pope, M., Kanemoto, R., Dowling, T. E., SaAri, L. L. \& Triplette, E. (1984). Regulation of nitrogen-fixation in photosynthetic bacteria. In Advances in Nitrogen Fixation Research, pp. 181-187. Edited by C. Veeger \& W. E. Newton. The Hague: M. Nijhoff \& W. Junk.

Merril, C. R., Goldman, D. \& van Keuren, M. L. (1982). Simplified silver protein detection and image 
enhancement methods in polyacrylamide gels. Electrophoresis 3, 17-23.

Norel, F., Kush, A., Denefle, P., Charpin, N. \& ELMERICH, C. (1984). Nitrogen fixation in a tropical Rhizobium associated with Sesbania rostrata. In Advances in Nitrogen Fixation Research, p. 694. Edited by C. Veeger \& W. E. Newton. The Hague: M. Nijhoff \& W. Junk.

O'FARREL, P. H. (1975). High resolution two-dimensional electrophoresis of proteins. Journal of Biological Chemistry 250, 4007-4021.

Robson, R., Kennedy, C. \& Postgate, J. (1983). Progress in comparative genetics of nitrogen fixation. Canadian Journal of Microbiology 29, 954-967.
Sedmak, J. J. \& Grossberg, S. E. (1977). A rapid, sensitive and versatile assay for protein using Coomassie brilliant blue G-250. Analytical Biochemistry 79, 544-552.

Suhara, K., TAKemori, S., Katagiri, M., Wada, K., Kobayashi, H. \& Matsubara, H. (1975). Estimation of labile sulfide in iron-sulfur proteins. Analytical Biochemistry 68, 632-636.

Whiting, M. J. \& DilworTh, M. J. (1974). Legume root nodule nitrogenase. Purification, properties and studies on its genetic control. Biochimica et biophysica acta 371, 337-351. 